\title{
Mobile Health and Patient Engagement in the Safety Net: A Survey of Community Health Centers and Clinics
}

The mission of The Commonwealth Fund is to promote a high performance health care system. The Fund carries out this mandate by supporting independent research on health care issues and making grants to improve health care practice and policy. Support for this research was provided by The Commonwealth Fund. The views presented here are those of the authors and not necessarily those of The Commonwealth Fund or its directors, officers, or staff.

For more information about this brief, please contact:

Andrew Broderick, M.A., M.B.A.

Codirector

Center for Innovation and Technology in Public Health

Public Health Institute

andrew.broderick@gmail.com

To learn more about new publications when they become available, visit the Fund's website and register to receive email alerts.

\author{
Andrew Broderick and Farshid Haque
}

\begin{abstract}
Patient-centered technologies have emerged as a way to actively engage patients in care. The reach and potential of cell phones to engage diverse patient populations is great. Evidence of their effectiveness in improving health-related outcomes is limited. Researchers conducted an online survey of community health centers and clinics to assess if and how health care providers in the safety net use cell phones to support patient engagement. The findings indicate that the use of cell phones in patient care is at an early stage of deployment across the safety net. Organizations identify chronic disease management as an area where cell phones offer considerable potential to effectively engage patients. To promote widespread adoption and use, technical assistance to support the implementation and management of interventions, evidence-based or best practice models that highlight successful implementation strategies in care delivery, and the introduction of new payment or reimbursement policies will be essential.
\end{abstract}

\section{OVERVIEW}

Cell phones and other consumer digital technologies have emerged as potentially powerful tools to engage patients in health care. They can strengthen the efficacy of safetynet health systems by improving providers' capacity to reach vulnerable populations and actively engage them in their care. In the United States, minority and low-income people have a high level of cell phone adoption, ${ }^{1,2}$ and often use features such as text messaging ${ }^{3,4}$ and mobile Internet. ${ }^{5,6,7}$ Mobile health interventions frequently involve the use of text messaging to provide concise, timely, and customized care-related information in the form of reminders and motivational and educational messages. These notifications can promote self-management practices for chronic conditions, educate consumers about preventive care and personal wellness, and improve patients' adherence with recommended treatment.

Providers have the opportunity to enhance care delivery and strengthen patient engagement using these new forms of interactive health services that facilitate greater connectedness between patients and their care team. ${ }^{8}$ Safety-net communities, in particular, are at greater risk for chronic, preventable diseases. Perhaps more important, text messaging represents a desirable, low-cost means to amplify and reinforce patient-empowerment strategies among the populations they serve given the high penetration of cell phones, high literacy with text messaging, and low costs of implementation. Recent research with low-income patients in California found that continuity 
and connectedness are key predictors of patient empowerment and efficacy. ${ }^{9}$ Although few patients can currently communicate with their providers by text or e-mail, a majority of those who currently can find it useful, while many of those who can't are interested in doing so. ${ }^{10}$

This brief presents findings from an online survey of community health centers and clinics to assess how safetynet providers are using cell phones to support patient engagement. We surveyed approximately 200 leaders at urban and rural community health centers and clinics that offer health care services to low-income people, including those without insurance, between June and October 2013. This survey represents a first step in assessing the current status of the use of mobile health in engaging patients in care, and of health centers' organizational experience in selecting, adopting, and implementing mobile health as a tool for patient engagement. Survey respondents also identified barriers to deployment and actions that can advance mobile health within safety-net communities. The survey findings provide an emerging evidence base that can begin to inform the design of strategies and policies that will support safety-net providers in implementing mobile health more broadly across the system.

\title{
RESEARCH FINDINGS
}

\section{More Effectively Engaging Patients in Care Activities or Practices}

Most respondents (86\%, or 155 of 181 respondents) report that patient engagement has been challenging, particularly in areas related to the adoption of healthy behaviors and compliance with standard care recommendation and treatment protocols. When asked in which areas organizations would like to more effectively engage patients, the greatest number of respondents (89\%, or 160 of 180 respondents) said chronic disease management (Exhibit 1).

\section{Exhibit 1. Areas Where Organizations Would Like to More Effectively Engage Patients}

\author{
In which areas of health care management would your organization \\ like to more effectively engage patients?
}

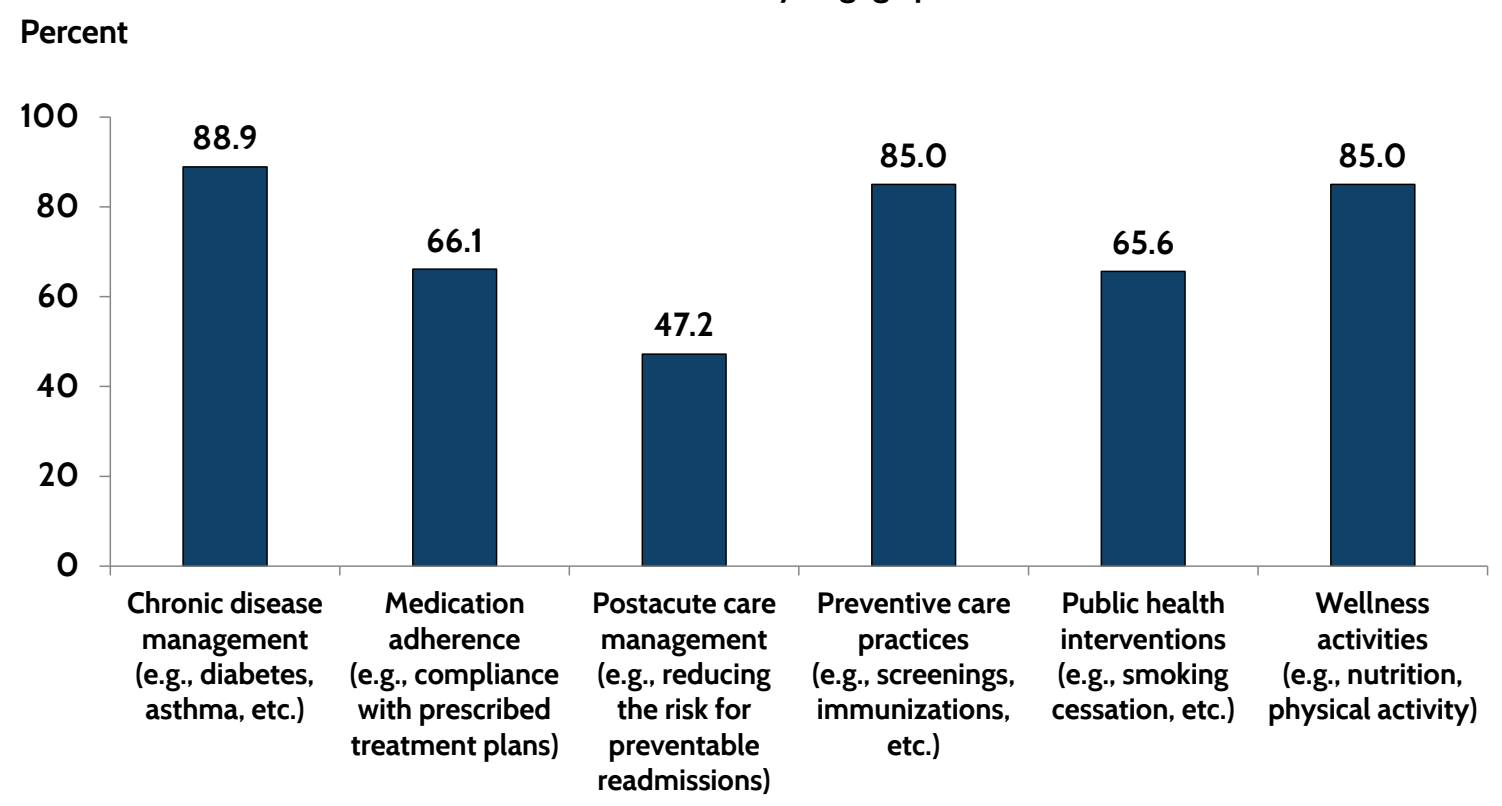




\section{Using Cell Phones in Patient Care}

Using cell phones as a tool for patient engagement remains at an early stage of deployment across the safety net, with just more than one-quarter $(27 \%$, or 48 of 180$)$ of respondents reporting they use cell phones in care delivery. Of the centers or clinics that do use cell phones in care, the most common application is to provide patients with appointment reminders (66\%, or 31 of 47 respondents) (Exhibit 2). Interventions to support chronic disease management, medication adherence, and smoking cessation remain at low levels, but organizations indicate they are planning to significantly increase their use within the next year.

\section{Exhibit 2. Implementation Status of Cell Phone Interventions Among Providers}

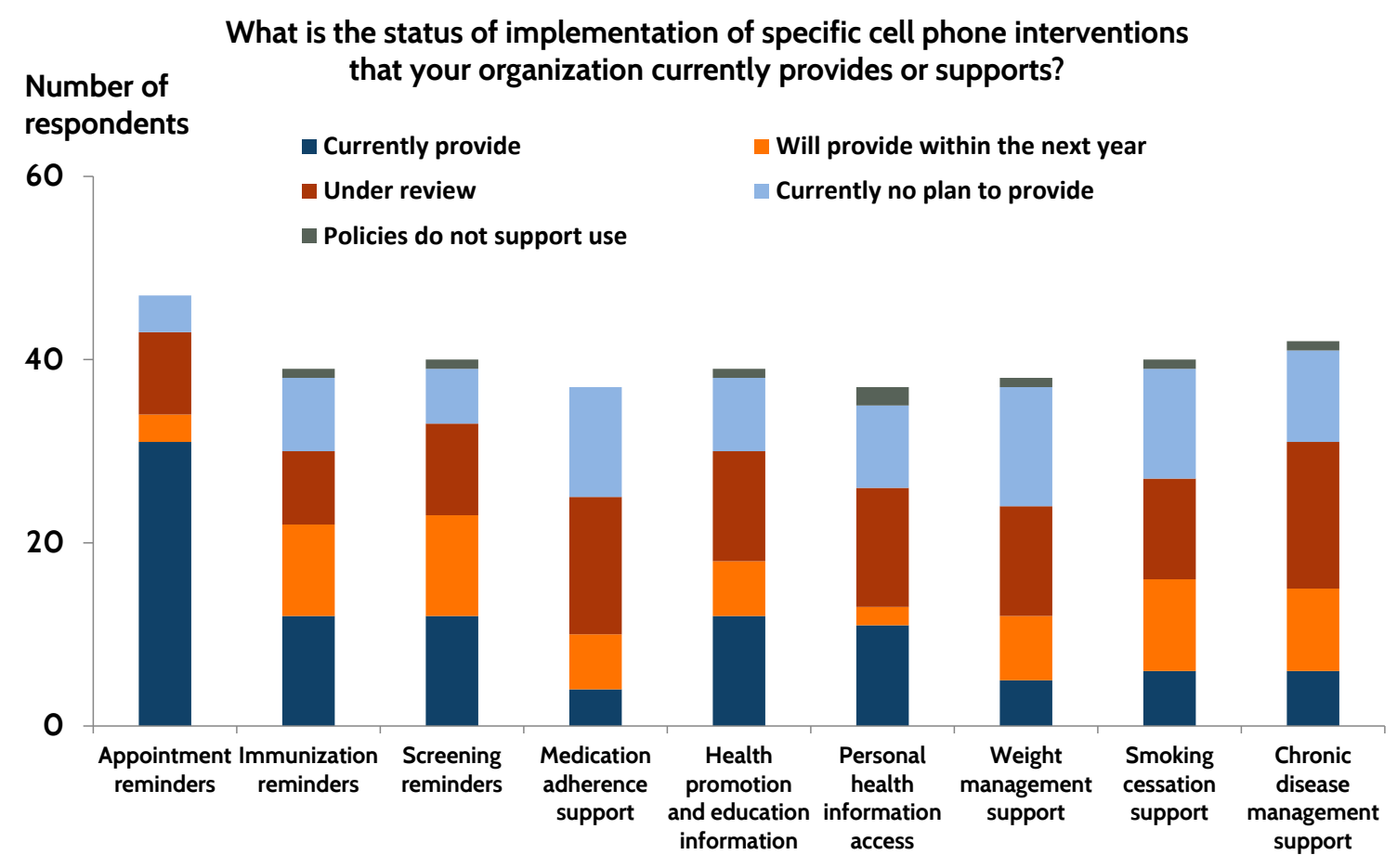

Source: Patient Engagement and Mobile Health in the Safety Net Survey, 2013.

\section{Benefits of Engaging Patients in Care}

Forty-two organizations (of 48) ranked the top three benefits of patients' use of cell phones. The ability to improve overall compliance with standard care practices (19 respondents), facilitate improved case management and targeted outreach (17 respondents), promote sustained patient engagement in behavior change (16 respondents), and improve compliance and prevent exacerbations of chronic conditions (15 respondents) ranked highest (Exhibit 3).

\section{Developing and Adopting Cell Phone Interventions}

We asked organizations about their strategies for developing mobile health interventions. Most have relied on their electronic health record (EHR) platforms and the ability of those platforms to support text-messaging applications (62\% of 42 respondents). A smaller number of organizations have collaborated with other health service organizations to codevelop interventions (10 respondents), contracted with mobile health solution providers ( 9 respondents), or developed proprietary technical or content elements (9 respondents) (Exhibit 4).

The survey asked center and clinic leaders about the criteria used to assess and justify the adoption of a cell phone intervention. More than half of respondents $(22$ of 40$)$ indicated the appropriateness of an intervention for use across 


\section{Exhibit 3. Patient Engagement Benefits \\ That Cell Phones Provide Organizations}

Rank the top three patient engagement benefits for your organization from patients' Number current use of cell phones in their care, with 1 being the most important

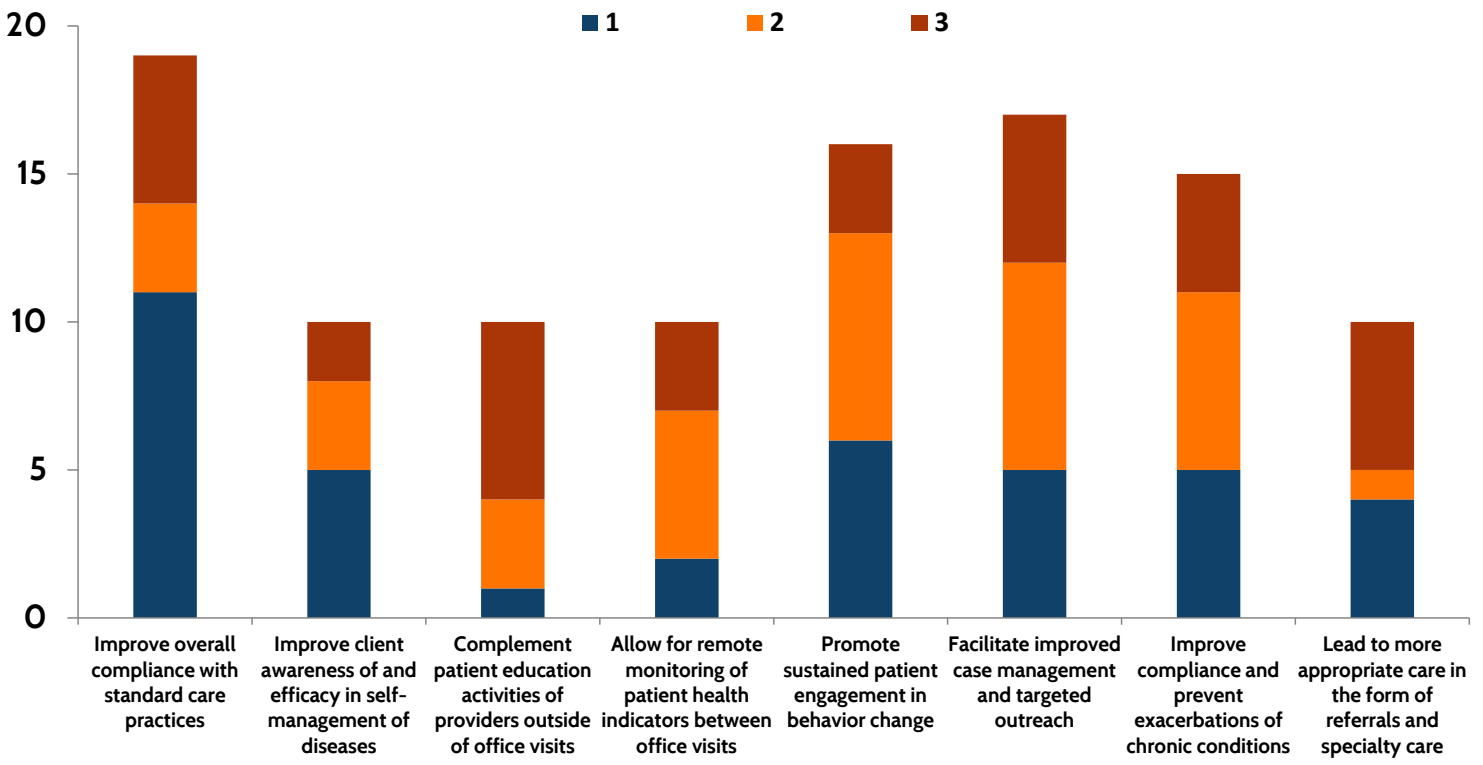

Source: Patient Engagement and Mobile Health in the Safety Net Survey, 2013.

\section{Exhibit 4. Safety-Net Provider Strategy for the Development of Cell Phone Interventions}

What has been your organization's strategy for the development of cell phone interventions that it currently provides or supports?

Percent

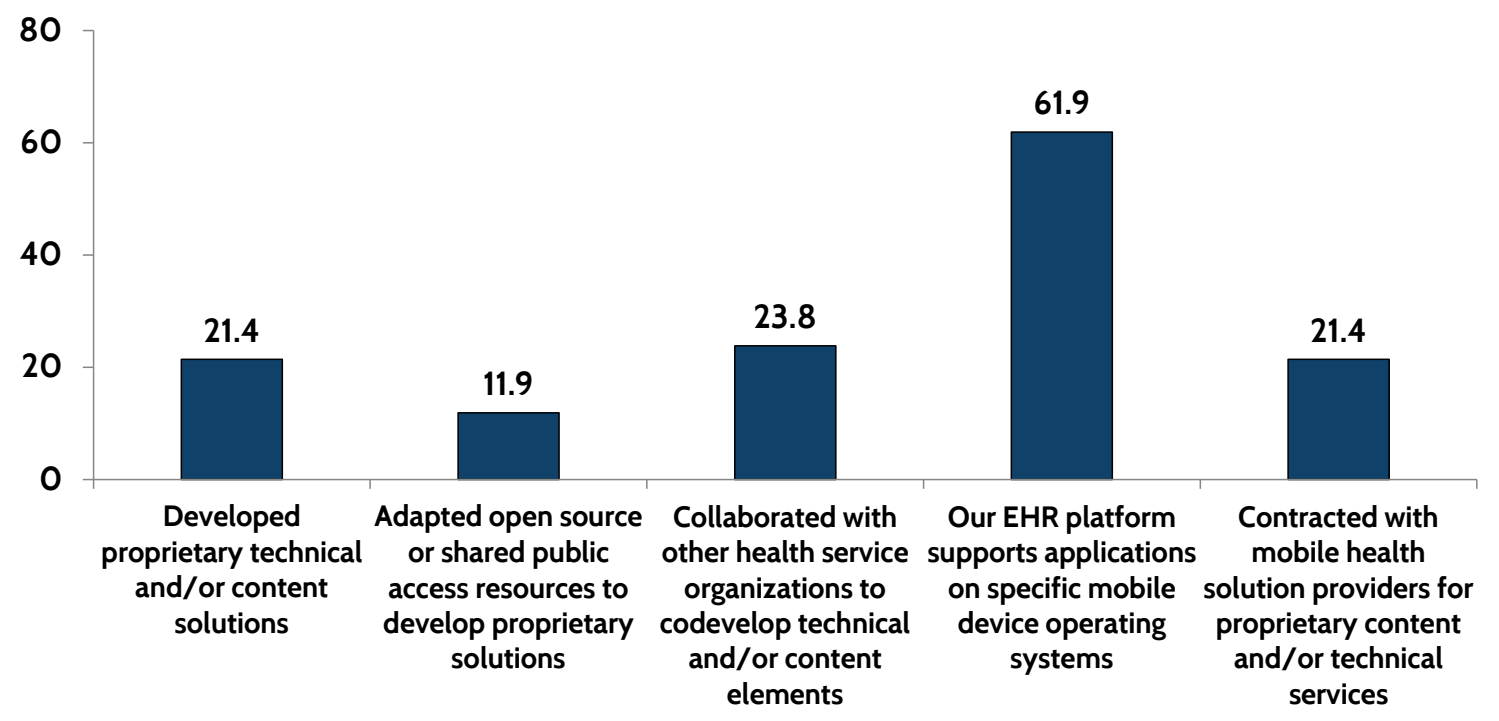




\section{Exhibit 5. Criteria Used to Assess and Justify the Adoption of Cell Phone Interventions}

Rank three criteria your organization has used to assess and justify the adoption of a cell phone intervention that it currently provides or supports, with 1 being the highest priority

\section{Number}

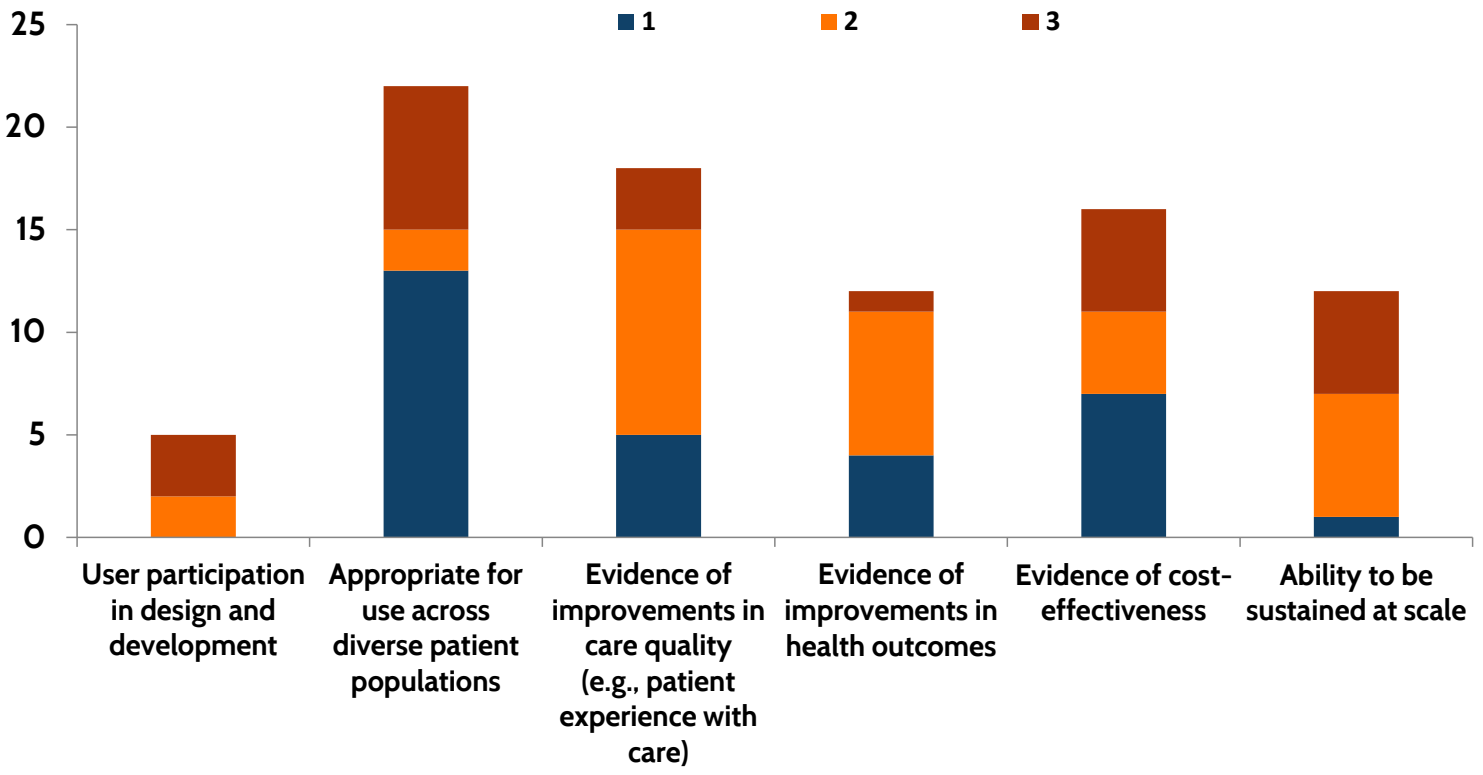

Source: Patient Engagement and Mobile Health in the Safety Net Survey, 2013.

diverse patient populations as the leading criterion. Evidence of improvement in care quality (18 of 40) as well as costeffectiveness (16 of 40) were also ranked as leading criteria. Only five respondents listed user participation in design and development (Exhibit 5).

\section{Barriers to Implementation and Actions to Encourage Adoption}

Of the 173 organizations that identified three leading barriers to implementing cell phone interventions, 94 cited a lack of external funding sources and 91 said limited human and technical resources. The next-most significant barrier (65 respondents) was the integration of mobile health solutions with electronic health records and other health information technology infrastructure (Exhibit 6).

The survey asked the organizations which criteria they view as essential to promote or justify adoption of a cell phone intervention. Of the 163 organizations that responded, most said technical assistance to support the implementation and management of interventions (106 respondents), evidence-based or best practice models of cell phone use in care delivery models (95 respondents), and the introduction of new payment or reimbursement policies for cell phone use in patient care (90 respondents) were most important (Exhibit 7). 


\section{Exhibit 6. Barriers to Implementation of Cell Phone Interventions}

Rank three barriers that your organization has identified with implementing cell phone interventions that engage patients in their care, with 1 being the highest priority

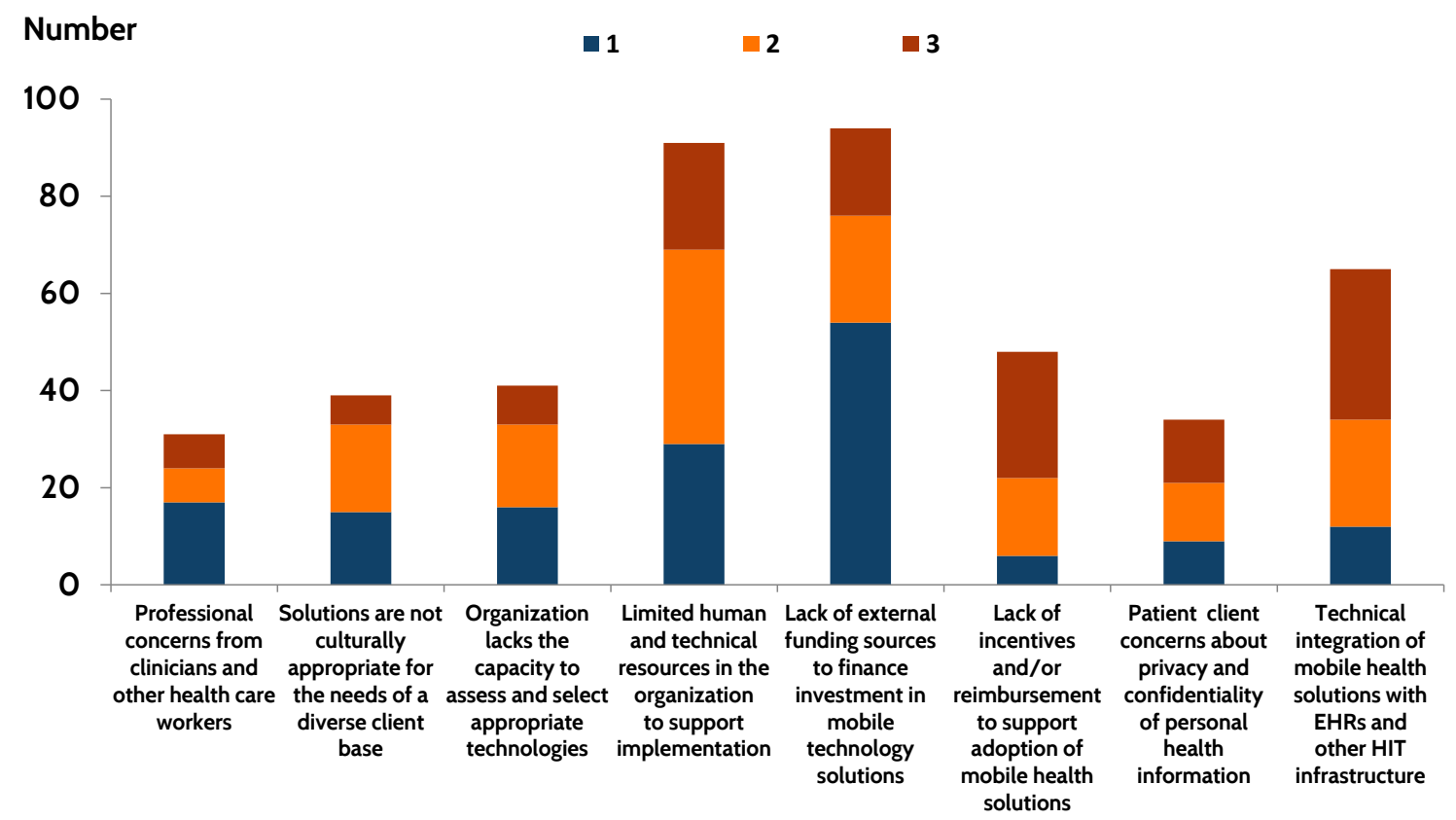

Source: Patient Engagement and Mobile Health in the Safety Net Survey, 2013.

\section{Exhibit 7. Actions to Promote the Adoption and Use of Cell Phone Interventions}

Rank three actions that your organization has identified as essential to promote the adoption and use of cell phone interventions that engage patients in their care, with 1 being the highest priority

Number

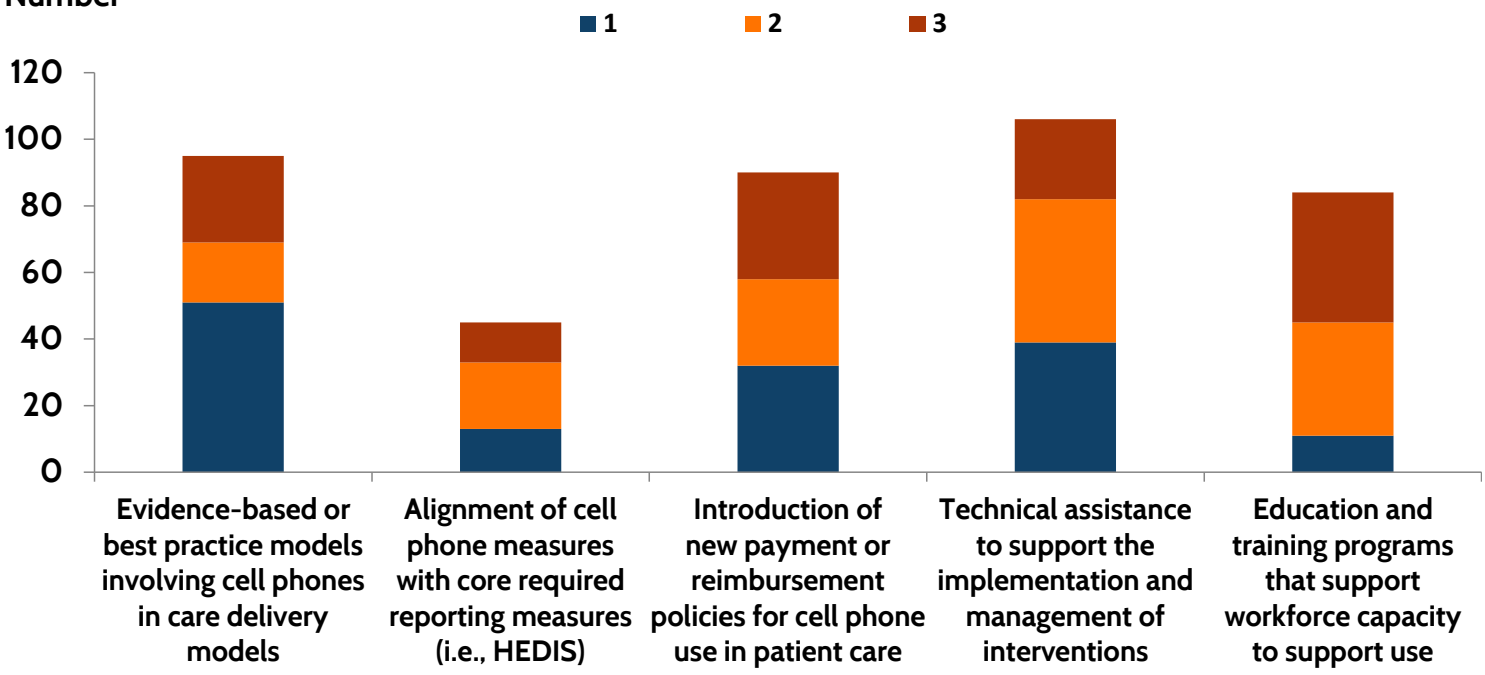




\section{DISCUSSION}

Digital technologies like cellular phones can increase the interactivity of health services and improve the capacity of public health organizations to care for underserved populations. In addition to improving patient engagement, mobile health solutions can support critical components of health reform, like patient-centered medical homes and accountable care organizations. There is limited evidence, however, of effectiveness in improving health-related outcomes with underserved populations and insufficient case studies that illustrate best practices or effective strategies for the deployment of interventions. Moreover, there are few financial and technical resources that can support implementation. Such limitations constrain organizations' abilities to realize the potential of digital health solutions.

On a larger scale, using technology to promote patient-centered, coordinated care can help make significant advances in improving population health and reducing inefficiencies in care delivery. But, as the findings from this survey reveal, providers have not been able to effectively leverage technology tools toward these goals. To fully unlock the potential of technology to improve health care will require an improved understanding of the use of mobile health in patient care, as well as policies that provide funding, technical assistance, and reimbursement and address the issues of informed consent, privacy and security. 


\section{METHODOLOGY}

This brief presents findings from an online survey of a national sample of urban and rural community health centers and clinics on their current use of and experiences with the implementation of mobile health solutions. The survey instrument was designed with input from key informant interviews, and questions were designed with a multiplechoice format and programmed with skip logic. Our sample frame of safety-net providers comprises urban and rural community health centers and clinics that offer health care services to low-income people, including those without insurance, and represents a subset of the larger health care safety-net provider system and the even-larger health care system beyond the safety net. National outreach to the senior leadership of 959 organizations nationwide took place between June and October 2013 and resulted in 230 organizations participating in the survey, of which 181 were completed and included in our final analysis (18.9\% response). Exhibit M1 shows the response rates for organizations by state and in relation to the number of Health Resources and Services Administration's Bureau of Primary Care grantees by state.

\section{Exhibit M1. Survey Response Rates by State}

\begin{tabular}{|c|c|c|c|c|c|c|c|}
\hline State & $\begin{array}{c}\text { Number of } \\
\text { Respondents }\end{array}$ & $\begin{array}{l}\text { Number } \\
\text { of HRSA } \\
\text { Grantees }\end{array}$ & $\begin{array}{c}\text { Response } \\
\text { Rate }\end{array}$ & State & $\begin{array}{c}\text { Number of } \\
\text { Respondents }\end{array}$ & $\begin{array}{l}\text { Number } \\
\text { of HRSA } \\
\text { Grantees }\end{array}$ & $\begin{array}{c}\text { Response } \\
\text { Rate }\end{array}$ \\
\hline $\mathrm{AL}$ & 1 & 15 & $6.7 \%$ & MT & 6 & 17 & $35.3 \%$ \\
\hline AK & 4 & 25 & $16.0 \%$ & $\mathrm{NC}$ & 6 & 32 & $18.8 \%$ \\
\hline AR & 7 & 12 & $58.3 \%$ & ND & 3 & 4 & $75.0 \%$ \\
\hline$A Z$ & 2 & 17 & $11.8 \%$ & NE & 1 & 6 & $16.7 \%$ \\
\hline $\mathrm{CA}$ & 61 & 129 & $47.3 \%$ & $\mathrm{NH}$ & 0 & 10 & $0.0 \%$ \\
\hline $\mathrm{CO}$ & 5 & 17 & $29.4 \%$ & NJ & 2 & 20 & $10.0 \%$ \\
\hline $\mathrm{CT}$ & 2 & 13 & $15.4 \%$ & NM & 2 & 15 & $13.3 \%$ \\
\hline $\mathrm{DE}$ & 0 & 3 & $0.0 \%$ & NV & 2 & 2 & $100.0 \%$ \\
\hline $\mathrm{FL}$ & 3 & 48 & $6.3 \%$ & NY & 15 & 57 & $26.3 \%$ \\
\hline $\mathrm{GA}$ & 5 & 28 & $17.9 \%$ & $\mathrm{OH}$ & 0 & 36 & $0.0 \%$ \\
\hline $\mathrm{HI}$ & 0 & 14 & $0.0 \%$ & OK & 4 & 18 & $22.2 \%$ \\
\hline ID & 3 & 11 & $27.3 \%$ & OR & 4 & 29 & $13.8 \%$ \\
\hline IL & 12 & 42 & $28.6 \%$ & $\mathrm{PA}$ & 14 & 40 & $35.0 \%$ \\
\hline IN & 2 & 20 & $10.0 \%$ & $\mathrm{RI}$ & 1 & 8 & $12.5 \%$ \\
\hline IA & 2 & 14 & $14.3 \%$ & $\mathrm{SC}$ & 3 & 20 & $15.0 \%$ \\
\hline $\mathrm{KS}$ & 0 & 16 & $0.0 \%$ & SD & 1 & 6 & $16.7 \%$ \\
\hline $\mathrm{KY}$ & 2 & 21 & $9.5 \%$ & $\mathrm{TN}$ & 2 & 26 & $7.7 \%$ \\
\hline LA & 4 & 26 & $15.4 \%$ & $\mathrm{TX}$ & 16 & 69 & $23.2 \%$ \\
\hline MA & 8 & 36 & $22.2 \%$ & UT & 2 & 11 & $18.2 \%$ \\
\hline MD & 2 & 16 & $12.5 \%$ & VT & 0 & 8 & $0.0 \%$ \\
\hline ME & 2 & 19 & $10.5 \%$ & VA & 1 & 24 & $4.2 \%$ \\
\hline MI & 14 & 32 & $43.8 \%$ & WA & 0 & 25 & $0.0 \%$ \\
\hline $\mathrm{MN}$ & 1 & 16 & $6.3 \%$ & WI & 0 & 17 & $0.0 \%$ \\
\hline MO & 1 & 23 & $4.3 \%$ & WV & 0 & 27 & $0.0 \%$ \\
\hline MS & 0 & 21 & $0.0 \%$ & WY & 2 & 5 & $40.0 \%$ \\
\hline
\end{tabular}




\section{NOTES}

1 A. Lenhart, Cell Phones and American Adults (Washington, D.C.: Pew Research Center, Sept. 2, 2010).

2 S. Fox and M. Duggan, Mobile Health 2012 (Washington, D.C.: Pew Research Center, Nov. 8, 2012).

3 A. Smith, Americans and Text Messaging (Washington, D.C.: Pew Research Center, Sept. 19, 2011).

4 Health Research Institute, Healthcare Unwired: New Business Models Delivering Care Anywhere (PricewaterhouseCoopers, 2010).

5 A. Smith, Nearly Half of American Adults Are Smartphone Owners (Washington, D.C.: Pew Research Center, March 1, 2012).

6 A. Smith, Smartphone Adoption and Usage (Washington, D.C.: Pew Research Center, July 11, 2011).

7 Fox, Mobile Health, 2012.

8 Televox, Technology Beyond the Exam Room: How Digital Media Is Helping Doctors Deliver the Highest Level of Care (Mobile, Ala.: Televox, 2012).

9 Blue Shield of California Foundation, Health Care in California: Leveling the Playing Field (San Francisco: Blue Shield of California Foundation, Nov. 2013).

10 Blue Shield of California Foundation, Building Better Health Care for Low-Income Californians (San Francisco: Blue Shield of California Foundation, Oct. 2013). 


\section{ABOUT THE AUTHORS}

Andrew Broderick, M.A, M.B.A., is a codirector at the Public Health Institute's Center for Innovation and Technology in Public Health, where he leads research and evaluation projects that advance the role of digital technologies into U.S. health care practice and policy, particularly among low socioeconomic populations. Mr. Broderick previously managed research activity at the Health Technology Center in San Francisco. Mr. Broderick holds a master's degree in economics and geography from Trinity College, Dublin, and a master's degree in business administration from San Francisco State University.

Farshid Haque, M.S., is the executive vice president and the chief customer solutions officer at Ellipsis Health. He holds master's degrees in community development and agricultural and resource economics, and is a medical geography Ph.D. candidate at the University of California, Davis. He was a Rockefeller Foundation global fellow in mobile health with the Public Health Institute. Mr. Haque has extensive teaching experience in community and regional development, and international agricultural development.

\section{ACKNOWLEDGMENTS}

The authors would like to acknowledge the contributions that key informants made through telephone-based interviews in sharing their experience and opinions to inform the design of the survey instrument, as well as the contributions of state primary care associations in facilitating outreach for the survey and the leadership of community health centers and clinics for providing data through the online survey.

Editorial support was provided by Deborah Lorber. 

www.commonwealthfund.org 